\title{
Death-feigning behavior in two species of Lygosoma (Squamata: Scincidae) from India
}

\author{
Harshil Patel ${ }^{1}$, Vaibhav Naik ${ }^{2}$, and Shantilal K. Tank ${ }^{1}$ \\ ${ }^{1}$ Department of Biosciences, Veer Narmad South Gujarat University, Surat, 395007, Gujarat, India. E-mail: harshilpatel121@ \\ gmail.com. \\ ${ }^{2}$ Valsad Pardi, Gopi Street, Valsad, 396001, Gujarat, India.
}

Keywords: defensive behavior, lizards, Lygosoma guentheri, Lygosoma punctata, thanatosis.

Palavras-chave: comportamento de defesa, lagartos, Lygosoma guentheri, Lygosoma punctata, tanatose.

Thanatosis (meaning "putting to death" in Greek) or death feigning is a form of defensive behavior in which an animal pretends to be dead when threatened or attacked by a predator (McFarland 1982). Death feigning has been reported across taxa and reported in mammals (Francq 1969), birds (Sargeant and Eberhardt 1975), fishes (McKaye 1981, Howe 1991), reptiles (Gomes et al. 2004, Bertoluci et al. 2006, Purkayastha and Das 2010, Ribeiro et al. 2010, Vogel and Han-Yuen 2010), amphibians (Sazima 1974, Bertoluci et al. 2007, Toledo et al. 2010), arthropods (Miyatake 2001, King and Leaich 2006), and molluscs (Zhang et al. 2009). Though widespread, there are few reports of thanatosis in Asian reptiles and only five records of it in reptiles from India-viz., Xenochrophis piscator (Schneider, 1799) (MacDonald 1947, Vogel and Han-Yuen 2010), Coelognathus radiatus (Boie, 1827) (Vogel and Han-Yuen 2010), Lycodon aulicus (Linnaeus, 1758) (Mirza et al. 2011), Pseudoxenodon macrops (Blyth, 1855) (Bhosale and Thite 2013), and Spheno-

Received 5 August 2016

Accepted 31 October 2016

Distributed December 2016 morphus maculatus (Blyth, 1853) (Purkayastha and Das 2010).

Here, we report thanatosis in two more species of Indian reptiles for the first timeLygosoma guentheri (Peters, 1879) and $L$. punctata (Gmelin, 1799). Lygosoma guentheri is an Indian endemic skink distributed across peninsular India (Figure 1A). It occurs at elevation up to $1800 \mathrm{~m}$. Lygosoma punctata is widely distributed in India, Pakistan, Sri Lanka, and Bangladesh (Figure 1B). It occurs at elevation up to $2500 \mathrm{~m}$ a.s.l. (Srinivasulu et al. 2014). Both skinks are diurnal, terrestrial, and insectivorous; little is known about the natural history of either species.

Opportunistic observations were made on skinks in their habitats at three localities in South Gujarat Region of Gujarat, India. The lizards were identified and photographed and then released in their respective habitats. Deathfeigning behavior was observed on three occasions. When possible, we photographed live skinks and individuals engaged in death feigning. On one occasion, we recorded a video to estimate the time the lizard remained immobilized. Deathfeigning behavior was observed twice in adult Lygosoma guentheri and once in a juvenile $L$. punctata. 

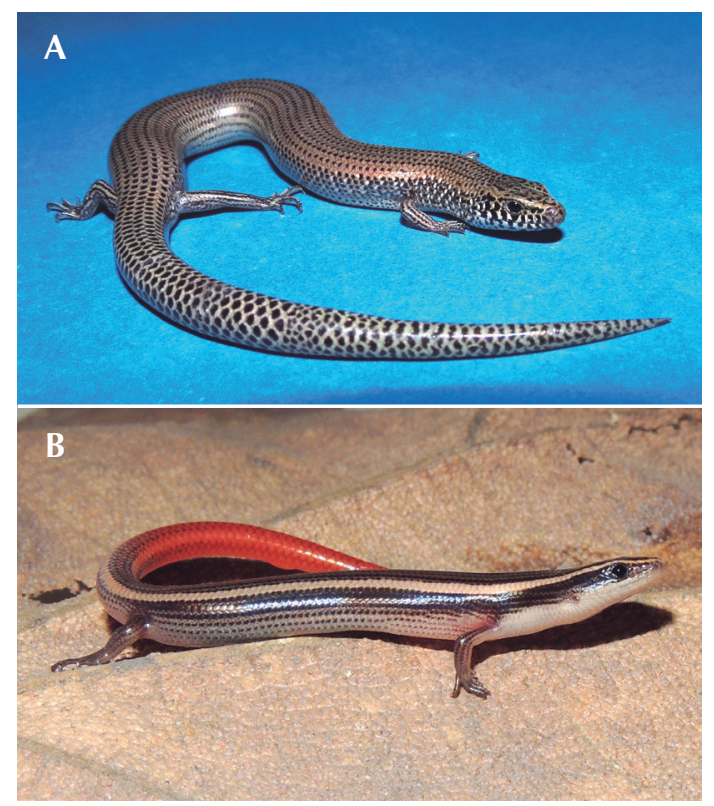

Figure 1. Living specimens of Lygosoma guentheri (A) and L. punctata (B).

On 01 May 2016 at about13:00 h, an adult Lygosoma guentheri (180 $\mathrm{mm}$ total length) was found under a rock in a mango orchard near the village of Valsad-Pardi, Valsad $\left(20^{\circ} 37^{\prime} 25.58^{\prime \prime} \mathrm{N}\right.$, $72^{\circ} 55^{\prime} 57.73^{\prime \prime} \mathrm{E} ; 13 \mathrm{~m}$ a.s.1.). When the skink was caught by hand, it immediately started writhing in an effort to escape. However, finding no way to escape, it turned over on its back to expose the venter. The skink extended its limbs and stiffened (Figure 2A). During the $50 \mathrm{~s}$ that the lizard maintained this position, we observed a rapid heartbeat, after which the skink slowly began to roll on its right side (Figure 2B). Then the skink rolled its anterior body slowly onto its anterior limbs and remained in that position for about $70 \mathrm{~s}$ (Figure 2C). Subsequently, the skink rolled over quickly onto its feet and remained motionless for a few seconds (Figure 2D) and attempted a quick escape. The whole event lasted for nearly $2 \mathrm{~min}$ and $30 \mathrm{~s}$.
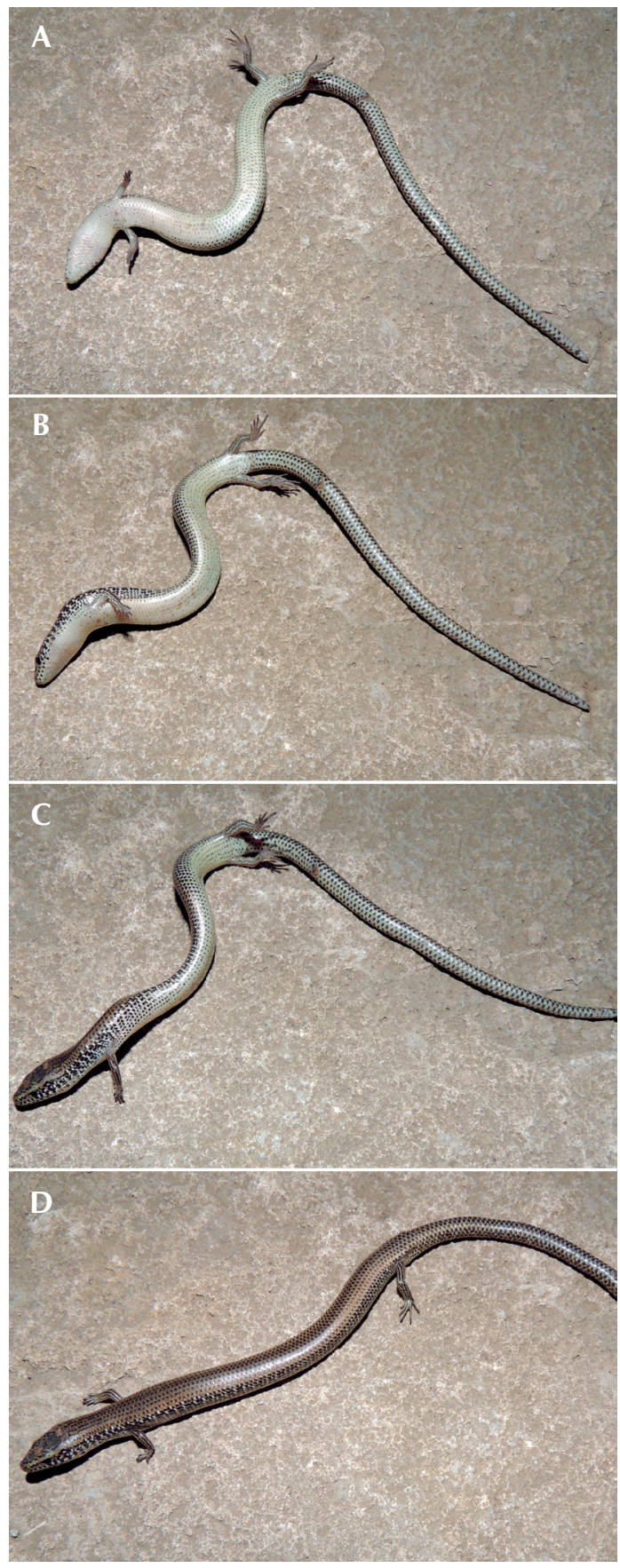

Figure 2. Sequence of death feigning behavior by an adult Lygosoma guentheri. See text for details. 
On 29 October 2015 at about 09:30 h, an adult Lygosoma guentheri (200 $\mathrm{mm}$ total length) was observed foraging on the ground on a plateau near the village of Piprol, Dharampur, Valsad (20'13'18.12" N, 73¹9'37.29" E; 435 m a.s.l.). When we approached, the skink took shelter under a nearby boulder. When the individual was caught by hand, it immediately began writhing to escape; then skink abruptly stopped moving and flipped on its back, exposing its venter. The lizard extended its limbs and stiffened (Figure 3), and remained immobile for about $25 \mathrm{~s}$ with a rapid heartbeat. After that, the skink quickly rolled over onto its feet and attempted to escape.

On 20 July 2014, a juvenile of Lygosoma punctata (130 $\mathrm{mm}$ total length) was seen foraging in leaf litter in moist deciduous forest floor at Vansda National Park, Navsari

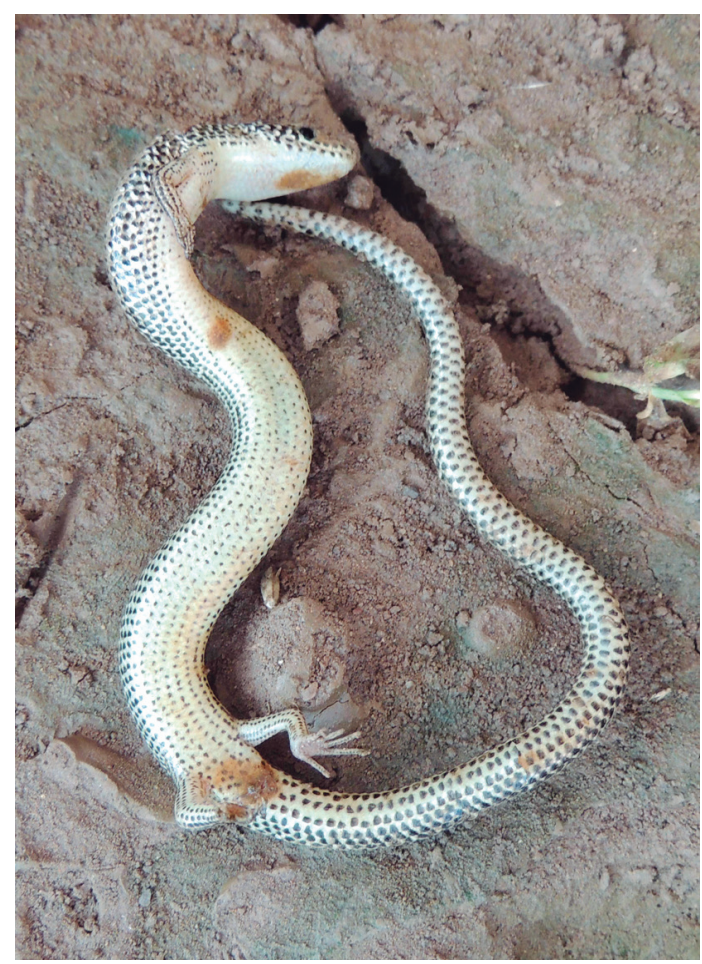

Figure 3. Death feigning by second individual of Lygosoma guentheri. $\left(20^{\circ} 45^{\prime} 3.07^{\prime \prime} \mathrm{N}, 7^{\circ} 28^{\prime} 50.86^{\prime \prime} \mathrm{E} ; 120 \mathrm{~m}\right.$ a.s.1.). When caught, skink moved its bright colored tail and tried to escape. After some time, it stopped moving and flipped on its back, showing its venter. It stiffened and remained immobile for about $10 \mathrm{~s}$, after which the skink rolled over onto its feet and escaped quickly in the nearby vegetation. We were unable to photograph this event.

It seems that death feigning is a tactic used by animals to manipulate predators by appearing to be dead before making an escape (Honma et al. 2006). Thanatosis has been reported primarily in snakes, and its occurrence in other reptiles is poorly documented; properly documented studies of this behavior and its role in survival of the animal are needed.

Acknowledgments.-We are thankful to Raju Vyas, Zeeshan Mirza, and two anonymous reviewers for valuable suggestions that benefited this manuscript. HP was supported by INSPIRE Fellowship (IF 130480) from the Department of Science and Technology (DST), New Delhi, India.

\section{References}

Bertoluci, J., J. Cassimiro, and M. T. Rodrigues. 2006. Tropiduridae (tropidurid lizards). Death-feigning. Herpetological Review 37: 472-473.

Bertoluci, J., R. A. Brassaloti, H. O. Sawakuchi, J. W. Ribeiro Jr., and G. Woehl Jr. 2007. Defensive behaviour with stiff-legged posture in the Brazilian tree toads Dendrophryniscus brevipollicatus and D. leucomystax (Anura, Bufonidae). Alytes 25: 38-44.

Bhosale, H. S. and V. Thite. 2013. Death feigning behavior in Large-Eyed False Cobra Pseudoxenodon macrops (Blyth, 1854) (Squamata: Colubridae). Russian Journal of Herpetology 20: 190-192.

Francq, E. N. 1969. Behavioral aspects of feigned death in the opossum Didelphis marsupialis. American Midland Naturalist 81: 556-568.

Gomes, F. R., T. Kohlsdorf, and C. A. Navas. 2004. Deathfeigning in Eurolophosaurus divaricatus: temperature and habituation effects. Amphibia-Reptilia 25: 321-325. 
Honma, A., S. Oku, and T. Nishida. 2006. Adaptive significance of death feigning postureas a specialized inducible defence against gape-limited predators. Proceeding of the Royal Society B 273: 1631-1636.

Howe, J. C. 1991. Field observations of death feigning in the Convict Tang, Acanthurus triostegus (Linnaeus), with comments on the nocturnal color pattern in juvenile specimens. Journal of Aquariculture and Aquatic Sciences 6: 13-15.

King, B. H. and H. R. Leaich. 2006. Variation in propensity to exhibit thanatosis in Nasonia vitripennis (Hymenoptera: Pteromalidae). Journal of Insect Behavior 19: 241-249.

MacDonald, A. St. J. 1947. Shamming death. Journal of the Bombay Natural History Society 47: 173.

McFarland, D. 1982. The Oxford Companion to Animal Behaviour. Oxford. Oxford University Press. 672 pp.

McKaye, K. R. 1981. Field observation on death feigning: a unique hunting behavior by the predatory cichlid, Haplochromis livingstoni, of Lake Malawi. Environmental Biology of Fishes 6: 361-365.

Mirza, Z., V. Vaze, and R. Sanap. 2011. Death feigning behavior in two species of the genus Lycodon of Asia. Herpetology Notes 4: 295-297.

Miyatake, T. 2001. Diurnal periodicity of death-feigning in Cylas formicarius (Coleoptera: Brentidae). Journal of Insect Behavior 14: 421-432.
Purkayastha, J. and M. Das. 2010. Sphenomorphus maculatus (Sauria: Scincidae): a case of death-feigning. Herpetology Notes 3: 285-287.

Ribeiro, S. C., J. G. G. Sousa, D. A. Teles, W. O. Almeida, and M. C. Guarnieri. 2010. Mabuya arajara $(\mathrm{NCN})$. Death-feigning. Herpetological Review 41: 494-495.

Sargeant, A. B. and L. E. Eberhardt. 1975. Death feigning by ducks in response to predation by red foxes (Vulpes fulva). American Midland Naturalist 94: 108-119.

Sazima, I. 1974. Experimental predation on the leaf-frog Phyllomedusa rohdei by the water snake Liophis miliaris. Journal of Herpetology 8: 376-377.

Srinivasulu, C., B. Srinivasulu, and S. Molur (Compilers). 2014. The Status and Distribution of Reptiles in the Western Ghats, India. Conservation Assessment and Management Plan (CAMP). Coimbatore. Wildlife Information Laision Development Society. 148 pp.

Toledo, L. F., I. Sazima, and C. F. B. Haddad. 2010. Is it all death feigning? Cases in anurans. Journal of Natural History 44: 1979-1988.

Vogel, G. and H. K. Han-Yuen. 2010. Death feigning behavior in three colubrid species of tropical Asia. Russian Journal of Herpetology 17: 15-21.

Zhang, M., Y. Zong, X. Wang, X. Cai, and Z. Zhang. 2009. Study on the death-feigning behavior of the Harmful Mollusk, Cathaica fasciola (Draparnaud 1801). Scientia Agricultura Sinica 42: 3914-3921.

Editor: Jaime Bertoluci 